\title{
2 \\ The Changing Roles of For-Profit and Nonprofit Welfare Provision in Norway, Sweden, and Denmark
}

\author{
Karl Henrik Sivesind
}

\section{Introduction}

It is not so obvious that there is a Scandinavian welfare model if we look at how the service provision is organized, as the data presented in this chapter will show. Common features can primarily be recognized as ideals concerning equal access for all to high-quality welfare services in core areas of education, health, and social services. In addition, in all Scandinavian countries, citizens have rights to participate in decision-making. Adaptation of services to individual needs, interests, and preferences has been reinforced legally and through new best practices and professional standards. Another common objective is to decentralize governance to the municipalities and to lower administrative levels in order to adapt policies to local needs.

An additional common feature is the broad implementation of new public management (NPM) tools, influenced by global trends since the

\footnotetext{
K.H. Sivesind ( $\square)$

Institute for Social Research, Oslo, Norway

e-mail: k.h.sivesind@socialresearch.no

(C) The Author(s) 2017

K.H. Sivesind and J. Saglie (eds.), Promoting Active Citizenship,

DOI 10.1007/978-3-319-55381-8_2
} 
eighties. Market-emulating types of governance increasingly regulate relations between public contracting authorities and providers of welfare services from nonprofit, for-profit, and public sector. EU directives and stronger national regulation of public procurement are important reasons for this, as the next chapter by Segaard and Saglie will show. Still, there is very broad political agreement about continued public funding and regulation of core welfare services. All these intentions are clearly expressed in policy documents from all the Scandinavian countries.

Despite common welfare ideals and the similar changes in regulation to other EU countries, this chapter will show that there are large differences in the employment shares of the for-profit, nonprofit, and public welfare providers among the Scandinavian countries. Rather than a single model, the situation resembles a natural experiment since different modes of regulation are used in different countries and service areas in order to better reach the same welfare goals. This is partly a result of historical differences, but recent policy initiatives and administrative reforms have increased the diversity in governance structures.

NPM reforms are influenced by international trends sweeping through advanced welfare societies. Priorities have shifted from the state as a social provider for the people to the state as a promoter of global competitiveness, Taylor-Gooby claims (2008: 4). Hence, in Scandinavia, the income tax percentage has gone down, and the welfare costs as shares of GDP have decreased slightly, while at the same time countries such as France, Austria, Germany, and Belgium have been catching up. In that way, the Scandinavian countries have become more similar to other rich, Western European countries. As a consequence, to reduce the gap between stagnating public benefits and higher income levels, more people sign up for private pensions and insurances for illness and disability.

The social investment thinking has not only consequences for transfers and entitlements but also for reforming the welfare service provision in order to improve the quality of education and health services and getting people back into the labour market, expecting that this will pay off in the future. In order to stay globally competitive, it is also necessary to cut costs and increase efficiency in services that the government pays for. In Scandinavia, there is a widespread worry that the dominating public service provision has become bureaucratized and stale. Many therefore 
see increased private provision of the state-funded services as an instrument for improving capacity, but more importantly, for creating competition, freedom of choice, and ultimately innovation to advance also the public service provision. However, the discussion about public versus private service delivery often overlooks the potential for pioneering and distinctive roles of nonprofit providers that initiated most of the welfare services we have today (Sivesind 2008).

In short, policymakers are worried that the public welfare spending may not give the best results, and to find out they wanted to create competition. This is the background for a very broad implementation of new public management tools and quasi-markets in Scandinavia. It all started when local governments made an internal separation between contracting authorities and providers of services. This happened in the beginning of 1990s in Sweden (Erlandsson et al. 2013, 27) and late in the 1990s in Denmark and Norway (Vabø et al. 2013, 171). Since then, responsibilities for results have been increasingly decentralized from political councils to lower administrative levels and even to semi-autonomous agencies, for example, regional health authorities in Norway. Frame agreements between public purchasers and service providers that would almost automatically be renewed are being replaced by contract negotiations, open tenders, and user choice in combination with voucher systems with national agencies authorizing service providers. This latter model has been spreading rapidly to new service areas and governance levels in Sweden since the 1990s, and it is recently getting wider implementation in Norway and Denmark as well.

User choice, influence, and adaptation are backed by several recent policy documents from all the Scandinavian countries pointing out that the dominant public provision is no longer capable of meeting new challenges that endanger the welfare model's sustainability. This includes the emergence of new groups of young users, more old people with a need for different kinds of help, limited personnel resources, increased private prosperity, and more social and cultural heterogeneity (An example from Norway is Report to the Storting (White Paper) nr. 29 2012-2013). These changes make recipients of all kinds of services require adaptation to individual needs. Traditional, standardized welfare services are struggling to meet these challenges. 'To secure the future 
legitimacy and sustainability' of the model, these policy documents claim that it is necessary to promote active citizenship by empowering the users and their next of kin to influence the content of services and also to assume more responsibility for the services. All sectors of society must be involved, including the voluntary engagement of families, local communities, nonprofit organizations, and social enterprises. Already in the 1980 s, a change in policy orientation from a welfare state to a welfare society was announced. This development must continue, according to the recent policy documents. Consequently, the division of labour between public, nonprofit, and for-profit providers, which is the topic of this chapter, is critical for the future of the welfare model.

Despite common welfare ideals and the similar changes in regulation as in many other European countries, differences in the mix of providers of publicly funded welfare services between the Scandinavian countries continue to evolve. This is partly a result of path dependencies. Denmark has the largest shares of nonprofit welfare provision in Scandinavia, but on a level below what has been called the Western-European welfare partnership countries, which include Germany, France, and Austria (Salamon et al. 2004; Salamon and Sokolowski 2016). Norway has a mixed model; there is a strong dominance of public welfare provision in some areas combined with a small share of nonprofit actors, but quasi-markets and open tendering in more areas have brought for-profits on the rise. However, in the 1990s, Sweden broke away from the past with strong public-sector dominance and opened up for rapid growth in profit-oriented private services. To complicate the picture further, different modes of regulation are used in different service areas in each country.

The next section shows changes in the employment shares of welfare service providers from the nonprofit, for-profit, and public sector in Scandinavia. This is followed by more detailed mapping of changes in the service areas education, health, and social services in each country. This will be related to changes in how public contracts are allocated to welfare service providers in the nonprofit, for-profit, and public sectors. The conclusion looks at path dependencies and policy initiatives that can explain why common welfare ideals and the implementation of similar NPM tools of government do not lead to convergence among the 
Scandinavian countries. On the contrary, there are increasing differences in the shares of providers of publicly funded services. Furthermore, there is no convergence with other welfare models either, and certainly not in the Swedish case.

\section{Divergence in Welfare Provider Mix among the Scandinavian Countries}

In Scandinavia, core welfare services in health, social services, and education continue to receive public funding to a comparatively high degree, and the government has assumed a larger part of the responsibility from the families than in other parts of Europe. This is what is commonly called the Nordic model in welfare research (Ervasti et al. 2008). These state-funded services have a huge impact on the lives of most of the population. In the following, we will be looking at changes in the shares of these services that are provided by the nonprofit, for-profit, and public sectors. To do that, we need a common measure that is comparable between countries and different service areas. Data on output are not available for all welfare service areas, and they are difficult to operationalize in a coherent manner. For example, it is difficult to compare the number of nursing home beds with pupils in primary schools. Alternatively, if we use expenditures as a proxy for output, the results may show a too large public sector because it often pays for costly treatments and procedures in addition to expensive infrastructure and equipment. A simpler solution chosen here is to compare shares of paid full-time employment as a common measure for each sector's 'market share,' or, rather, workforce input. This should work reasonably well in welfare areas compared that are dominated by employment-intensive services. In Sweden, unfortunately, only data on the number of employees are available. Still, this gives valid measures of shares of the institutional sectors and changes within each country, assuming that the distribution of part-time and full-time employment does not change too much.

Table 2.1 shows paid employment in welfare services in the nonprofit, for-profit, and public sectors, covering the longest time spans for which 
comparable data are available. This started in the year 2000 in Sweden, 2008 in Denmark, and 2006 in Norway, and ended in 2013 for all three countries. Although for a limited number of years, this is the first time comparable data on broad changes in welfare provider mix from the Scandinavian countries can be presented. The data show employment shares of the public, for-profit, and nonprofit sector providers in publicly funded welfare in the service areas education, health, and social services. To facilitate comparison between countries with data covering different time spans, changes in 5-year averages have been shown in Table 2.1. This means how much of the total employment each sector has gained or lost over the whole available data period in average for 5 years.

Table 2.1 shows that oil-rich Norway experienced a strong growth in the total welfare sector employment between 2006 and 2013 with as much as $12 \%$ increase in a 5 -year average, in a period when other countries struggled with a financial crisis. In Sweden, the increase in the number of employees was $7 \%$ in a 5-year average between 2000 and 2012, whereas in Denmark there has been almost no change at all between 2004 and 2013. The data on employment in the different economic sectors come from the national statistical agencies (see sources and typologies in the appendix at the end of the chapter).

Table 2.1 shows furthermore that the nonprofit sector's share of paid employment in 2013 was $8 \%$ in Norway, 3\% in Sweden, and 14\% in Denmark. These shares have been quite stable for a long time. The changes in shares were $1 \%$ point or less in 5-year averages. In fact, documentation from the Johns Hopkins Comparative Nonprofit Sector Project shows that the nonprofit share in Norway has been stable on about $7.5 \%$ of the full-time welfare employment back to 2004 and 1997 (Sivesind 2008a; Sivesind et al. 2004). In Sweden, the nonprofit share of welfare employees was just $2 \%$ in 1992, peaked at 3.5\% in the year 2000 (Lundström and Wijkström 1997; Sivesind and Selle 2010), and then decreased slightly to $3.2 \%$ in 2013 . The growth was partly due to the fact that since 2000, the Church of Sweden is no longer under state governance. This added 24,000 church employees to the nonprofit sector in several areas, including welfare services. In addition to this, the number of employees increased in social services (9100), education (1600), and health (800) (Wijkström and Einarsson 2006, 59). In Denmark, the 


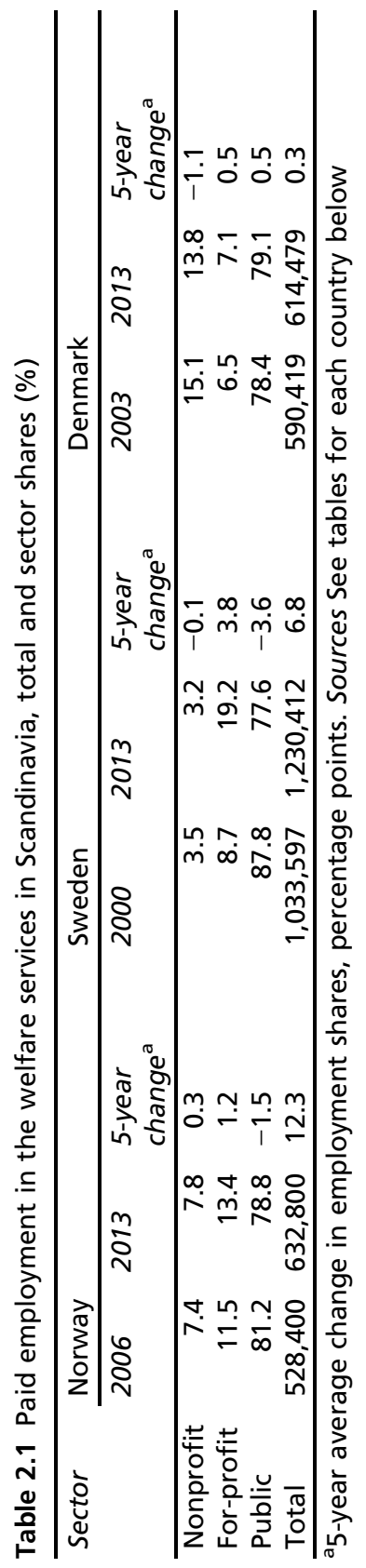


nonprofit share was $16.5 \%$ in 2003 , as shown in the data from the Hopkins project (Boje et al. 2006, Table 5.9), but then it decreased to 13.8 in 2013 (Boje 2017). A more detailed analysis in the section about Denmark below shows that this may be a result of particular reforms in the social service area rather than a trend, at least for now.

However, employment shares do not tell the whole story. Because of different trends in total welfare employment growth, the nonprofit sector in Norway has increased strongly in real numbers from 39,000 to 50,000 full-time employees from 2006 to $2013,{ }^{2}$ even though the share only increased by $0.3 \%$ points in a 5 -year average. Even in Sweden, with $0.1 \%$ points decline in a 5 -year average, there is a very small real increase from 36,000 to 39,000 employees from 2000 in 2013. In contrast, Denmark, with a more stable total welfare employment and a nonprofit sector decline of $1.1 \%$ points in a 5-year average, had a decrease in the number of nonprofit sector full-time employees from 93,000 to 85,000 from 2003 to 2013, respectively.

It is important to note that the nonprofit welfare shares in all Scandinavian countries are much smaller than in welfare partnership countries such as Austria, Germany, and France with well-established, partly church-based welfare services and nonprofit welfare employment shares between 20 and 25\%. The UK, as an example of a more liberal model, has nonprofit welfare provision on the same high level, but the services are funded and organized in a different manner. In fact, the levels in Sweden and Norway are only comparable to Eastern European countries that still are marked by the communist era when the nonprofit sector was kept at a minimum (Salamon and Sokolowski 2016; Sivesind and Selle 2010).

There are large differences in the for-profit sector shares among the Scandinavian countries in the most recent data. In Sweden, the share of the welfare employees is $19 \%$, while in Norway the share of welfare full-time employment is $13 \%$, and in Denmark just $7 \%$. There has been growth in for-profit employment shares in all three countries, but mostly in Sweden. In 5-year averages, there was a little more than $1 \%$ point growth in Norway and half a percentage point growth in Denmark, but almost $4 \%$ points growth in Sweden. This may seem like a small change, but it means that the for-profit sector in Sweden has doubled its share of 
the welfare employees from 9 to $18 \%$ from 2000 to 2013, and the number of employees has become more than 2.5 times larger, increasing from 90,000 to 236,000 . This is a change rate that in the long term has the potential of transforming the welfare model in Sweden. In Norway, there has also been an increase in for-profit welfare from 61,000 full-time employees in 2006 to 84,500 in 2012. In Denmark, which has the smallest share of $7.1 \%$, there has been a real growth from 38,000 to 44,000 full-time employees.

At the moment, the public-sector employment share is almost the same in all three Scandinavian countries, between 78 and $79 \%$ of the welfare employment. However, it is decreasing rapidly in Sweden with$3.6 \%$ points in a 5 -year average and $-1.5 \%$ points in Norway, but it is increasing by $0.5 \%$ points in Denmark. In Norway, the public sector is still growing in real numbers, from 429,000 full-time employees in 2006 to 500,000 in 2013. In Denmark, the public sector reached a maximum in 2010 with 549,000 full-time employees, and in Sweden it peaked in 2007 with 974,000 employees. ${ }^{3}$

Although the public-sector shares still may seem large in comparative perspective, they are decreasing in real numbers primarily as a result of for-profit growth. This adds a new feature to the 'social democratic model', previously characterized by high public welfare spending and a small nonprofit sector. The public sector was preferred as a service provider to ensure unitary standards and equal access for all (Anheier and Salamon 2006; Salamon and Anheier 1998). For-profit sector growth also sets the Scandinavian countries apart from the corporatist and liberal countries, which have much larger nonprofit sectors (Salamon et al. 2004).

To sum up, in Sweden, the public-sector employment has decreased in real numbers, and a decline has recently started in Denmark too. In Norway, with no need for austerity measures, all three sectors still grow in real numbers, although the public sector's share decreases slightly. In all three Scandinavian countries, the for-profit providers are increasing their shares of the welfare employment faster than the nonprofits. The gap between the sectors is growing fastest in Sweden, where the nonprofits remain very small while the for-profit share has doubled. This has resulted in a dramatic shift from the public sector to the for-profit sector 
in Sweden, and while the for-profit sectors grow in Norway and Denmark too, the changes in provider mix are more moderate. The changes in Sweden may have significant long-term consequences, because the tools of governance that have brought the public sector share down to the same level as the other Scandinavian countries are continuing to produce rapid growth in the for-profit sector but not in the nonprofit sector's share of employees.

The main focus of this chapter is on changes within 'education,' 'health,' and 'social services,' which include the sub-categories shown in Table 2.2. The data presentation thus follows as far as possible the International Classification of Non-Profit Institutions (ICNPO) (United Nations 2003). However, to match with national statistical categories that cannot be broken down, nursing homes (ICNPO 3 200) are moved from Health to Social Services, and Research (ICNPO 2 400), which is not typically regarded as one of the welfare services, is excluded from Education and Research (ICNPO 2). Table 2.2 shows sub-categories for the most important types of social services in Scandinavia, which, in addition to nursing homes and home-based care, are day-care for children, child and juvenile welfare, and substance abuse treatment. More specific details about sources and the typologies used in each country's statistics are presented in an appendix at the end of the chapter.

Table 2.2 Service areas included in ICNPO main categories

2 Education

2100 Primary and secondary education

2200 Higher education

2300 Other education

\section{Health}

3100 Hospitals and rehabilitation

3300 Mental health care

3400 Other health services

\section{Social Services}

3200 Nursing homes

4100 Social services, including day care for children, child and juvenile welfare, substance abuse treatment

Other social services including (4 200) emergency and relief

Note Adapted from International Classification of Non-Profit Institutions (United Nations 2003) 
In the following sections, we look at changes in the composition of providers within the welfare service areas in each of the Scandinavian countries. We also look at relations between the governments and the for-profit and nonprofit sectors that may explain the different trends.

\section{Denmark: Relatively Stable Welfare Provider Mix and a Large Nonprofit Welfare Share}

Denmark has the largest nonprofit shares in Scandinavia because of a long tradition of the government engaging voluntary organizations and self-owning institutions in social service provision. This is because nonprofit organizations have been pioneers in the welfare service area, as shown in an analysis of state-voluntary sector relations through the last 150 years (Henriksen and Bundesen 2004). Although many tasks have later been taken over by the public sector, self-owning institutions still perform a large part of the welfare services-often in close cooperation with the public sector. The nonprofit sector has a quite strong position in primary and lower secondary schools, where its share of pupils increased from 10 to $15.3 \%$ between 1990 and $2011 .{ }^{4}$ This recent growth is primarily a result of parents stepping in when the municipalities want to close schools with too few pupils, exercising their legal rights to establish schools with public funding. Free schools get state funding equivalent to $72 \%$ of the average costs for a pupil in the public schools. Above that, the schools can determine the level of fees paid by the parents. The traditional free schools are nonprofit institutions, but even a newer type of private schools operates on a nonprofit basis (see Chap. 3).

Table 2.3 shows that in education, the nonprofit sector had about $29 \%$ of the paid employment and increased from 53,000 to 55,000 full-time employees, while the public sector had $69 \%$ of the employment and an increase from 124,000 to 131,000 full-time employees. The for-profit educational institutions had a little more than 4,000 full-time employees, which is just $2 \%$ of the total employment in the service area. There were no changes in the employment shares in education, even though the total number of full-time employees increased from 181,000 to 190,000 . 
Table 2.3 Paid employment in the nonprofit, for-profit, and public sectors within education, health, and social services in Denmark 2008-2013, full-time equivalents and percent

\begin{tabular}{|c|c|c|c|c|}
\hline \multirow[t]{2}{*}{ Service area } & \multicolumn{2}{|l|}{2008} & \multicolumn{2}{|l|}{2013} \\
\hline & Employment & $\%$ & Employment & $\%$ \\
\hline \multicolumn{5}{|l|}{ Education (P) } \\
\hline Nonprofit & 52,823 & 29.1 & 54,736 & 28.7 \\
\hline For-profit & 4,291 & 2.4 & 4,405 & 2.3 \\
\hline Public sector & 124,153 & 68.5 & 131,255 & 68.9 \\
\hline Total & 181,266 & 100.0 & 190,396 & 100.0 \\
\hline \multicolumn{5}{|l|}{ Health (QA) } \\
\hline Nonprofit & 1620 & 1.3 & 623 & 0.5 \\
\hline For-profit & 21,268 & 16.5 & 23,116 & 16.7 \\
\hline Public sector & 105,703 & 82.2 & 114,534 & 82.8 \\
\hline Total & 128,590 & 100.0 & 138,273 & 100.0 \\
\hline \multicolumn{5}{|c|}{ Social services (QB) } \\
\hline Nonprofit & 34,700 & 12.4 & 29,651 & 10.4 \\
\hline For-profit & 12,673 & 4.5 & 16,106 & 5.6 \\
\hline Public sector & 233,190 & 83.1 & 240,053 & 84.0 \\
\hline Total & 280,563 & 100.0 & 285,810 & 100.0 \\
\hline \multicolumn{5}{|c|}{ Welfare field in total } \\
\hline Nonprofit & 89,142 & 15.1 & 85,010 & 13.8 \\
\hline For-profit & 38,232 & 6.5 & 43,627 & 7.1 \\
\hline Public sector & 463,046 & 78.4 & 485,842 & 79.1 \\
\hline Total & 590,419 & 100.0 & 614,479 & 100.0 \\
\hline
\end{tabular}

Sources See appendix at the end of the chapter

In health, the nonprofit share has for a long time been very small in Denmark because there are no large hospitals or other health institutions (Sivesind 2008b; Helander and Sivesind 2001; Boje 2006; Boje et al. 2006, Table 5.9). Table 2.3 shows that the employment has further decreased from 1,600 to 600 full-time employees from 2008 to 2013, which means that the share has gone down from 1.3 to $0.5 \%$. There are no important changes in the welfare mix; the for-profit and public sectors had about 17 and 82\% each of the employment from 2008 to 2013.

In social services, there were more profound changes. Table 2.3 shows that the nonprofit employment decreased from 35,000 to 30,000, and the employment share went down from 12 to $10 \%$. In contrast, the for-profits had a small increase from 4.5 to $5.6 \%$, and the public sector share also increased slightly from 83 to $84 \%$. The for-profit and public 
sectors had increases in full-time employees of 3500 and 7000, respectively.

In Denmark, the decrease in nonprofits was partly a result of a decrease in self-owning kindergartens from 23.5 to $20 \%$ from 2007 to 2011. Such self-owning daycare centers for preschool children must have an operating contract and be supervised by the municipality. Parent payments must be kept on the same level as similar public-sector services. A new type of private kindergartens may transfer profits to owners, in contrast to the self-owning institutions (see Chap. 3), but in practice most of them stick to the traditional nonprofit form. However, according to the definitions in UN's handbook for satellite accounts for non-profit institutions (United Nations 2003), they should be regarded as part of the for-profit sector, as long as there is no formal ban on profit distribution. Their share increased from 2.7 to $4.4 \%$, while the public sector has been rather stable at about 75\% (Thøgersen 2013).

In addition, the nonprofit employment share in social services decreased because the total number of institutions for elderly care decreased strongly as a result of a change towards home-based care, similar to the development in many other countries. However, in Denmark, this seems to have implied an increase in municipal and for-profit employment. Even though the share of self-owning, nonprofit institutions stayed between 20 and 22\% from 2000 to 2010, the number of employees decreased because of the reduction in the total number of institutions. In addition, several self-owning social service institutions were taken over by the public sector during a local government reform in 2007 that reduced the number of municipalities from 275 to 98 . Additionally, since 2007, it has been possible to establish a new type of 'independent' nursing home that does not need an operating contract with the municipalities, and that may transfer profit to owners (see Chap. 3). In 2012, they only had 7\% of the people enrolled in nursing homes in Denmark, but further growth can be expected since this is a relatively new form of organization (Thøgersen 2013).

When it comes to homes for disabled persons, the share of the self-owning institutions has been stable at around 25\% from 2008 to 2011. Among other institutions, such as shelters for battered women, hostels for the homeless, institutions for drug and alcohol addicts etc., 
about $50 \%$ are self-owning institutions. Before the responsibility was transferred from counties to municipalities in 2007, the share was stable at about 55\% from 2000 to 2006 (Thøgersen 2013). However, this is a complex field with overlapping types of services and institutions and frequent structure changes, so the statistics do not present the full picture. All in all, this results in a decrease in users of nonprofit social services and thereby also a reduction in the number of full-time employees, while the for-profit and public sectors increase.

\section{Sweden: Strong Growth in For-Profit Welfare}

Among the Scandinavian countries, the biggest change in welfare provider mix has happened in Sweden, which in the beginning of the 1990s probably had the highest proportion of public welfare services among the advanced welfare states in the world. The reasons for this were brought up in the introduction to the book and will be further discussed at the end of this chapter. In the new millennium, there have been dramatic changes in the Swedish welfare provider mix, as we have seen in Table 2.1 above, which shows changes for the welfare services in total from 2000 to 2013 . Table 2.4 shows that the changes vary between the service areas of education, health, and social service, but the data only cover 2007 to 2013 because there was a change in statistical categories before 2007. In the recent years, the nonprofit share has been small but stable in all three welfare service areas, with about $5 \%$ in education, just $1 \%$ in health, and $3 \%$ in social services. However, the for-profit services increased their share of employees rapidly with 4 percentage points to $14 \%$ in education, 3 percentage points to $19 \%$ in health, and as much as 8 percentage points to $25 \%$ in social services. This resulted in significant reductions in the public-sector shares, which went down from 86 to $81 \%$ in education, 84 to $80 \%$ in health, and as much as from 82 to $72 \%$ in social services from 2007 to 2013.

In education, the nonprofit and public sectors increased with a few thousand employees each, but the for-profits increased with 25,000 employees. In health the total number of employees declined with 12,000 , mainly in the public sector, while the for-profits increased by 
Table 2.4 Shares of paid employees in the nonprofit, for-profit, and public sectors within education, health, and social services in Sweden 2007-2013

\begin{tabular}{|c|c|c|c|c|}
\hline \multirow[t]{2}{*}{ Service area } & \multicolumn{2}{|l|}{2007} & \multicolumn{2}{|l|}{2013} \\
\hline & Employment & $\%$ & Employment & $\%$ \\
\hline \multicolumn{5}{|c|}{ Education (SNI 85) } \\
\hline Nonprofit & 22,284 & 4.9 & 24,660 & 5.1 \\
\hline For-profit & 42,754 & 9.5 & 68,175 & 14.2 \\
\hline Public sector & 385,757 & 85.6 & 388,547 & 80.7 \\
\hline Total & 450,795 & 100.0 & 481,382 & 100.0 \\
\hline \multicolumn{5}{|c|}{ Health (SNI 86) } \\
\hline Nonprofit & 3,768 & 1.2 & 2,485 & 0.8 \\
\hline For-profit & 46,168 & 14.8 & 56,456 & 18.7 \\
\hline Public sector & 262,770 & 84.0 & 242,411 & 80.4 \\
\hline Total & 312,706 & 100.0 & 301,352 & 100.0 \\
\hline \multicolumn{5}{|c|}{ Social services (SNI 87-88) } \\
\hline Nonprofit & 12,173 & 3.1 & 12,006 & 2.7 \\
\hline For-profit & 58,691 & 14.8 & 111,788 & 25.0 \\
\hline Public sector & 324,985 & 82.1 & 323,884 & 72.3 \\
\hline Total & 395,849 & 100.0 & 447,678 & 100.0 \\
\hline \multicolumn{5}{|c|}{ Welfare field in total } \\
\hline Nonprofit & 38,225 & 3.3 & 39,151 & 3.2 \\
\hline For-profit & 147,613 & 12.7 & 236,419 & 19.2 \\
\hline Public sector & 973,512 & 84.0 & 954,842 & 77.6 \\
\hline Total & $1,159,350$ & 100.0 & $1,230,412$ & 100.0 \\
\hline
\end{tabular}

Sources See appendix at the end of the chapter

10,000 employees, However, in social services, the number of for-profit employees almost doubled whereas the other sectors remained stable. This means that almost all growth in Swedish welfare employees has happened in the for-profit sector, with the biggest increase in social services.

In what services more specifically have the changes in provider mix occurred? The proportion of pupils in private schools, which was around $2 \%$ when private school reform was implemented in 1992, has increased to $15 \%$ in compulsory schools and to $25 \%$ in upper secondary schools in 2014 (Swedish National Agency for Education 2016). As much as 64\% of the private schools are limited companies (Vlachos 2011), and this share is increasing because there are few restrictions on the school owners' options to take out the surplus, which is quite unique for western welfare states. 
Within care for elderly and disabled, the nonprofit share has been stable around $2-3 \%$ over the past 20 years, while the share of private services has increased from almost nothing to $15 \%$ (Erlandsson et al. 2013; Szebehely 2011). Within care for individuals and families, which includes care for children and juveniles and substance abuse treatment, the private share grew strongly in the 1980s and 1990s, but there have only been minor changes since the year 2000. In 2010, a little less than $10 \%$ were employed in nonprofit organizations and $35 \%$ in for-profit companies (Wiklund 2011). Within hospitals and inpatient medical care, the share of private employment in Sweden is small, as in the other Scandinavian countries. About 4\% worked in 2009 in for-profit companies and $1 \%$ in nonprofit organizations and foundations. Within outpatient health and medical treatment, however, private companies have about one-third of the employees, and they have taken over an increasing share of the service area since 1995. Nonprofit organizations and religious communities and foundations are almost absent (Johansson 2011). The private share has, in comparative perspective, been quite low in this field in Sweden. In 1994, more than 90\% of the doctors were employed by the public sector, most of them by county councils (Zweifel et al. 1998). The emerging private sector consists largely of single units or smaller companies, besides some national chains that are either co-operatives owned by employees (Praktikertjänst) or corporations (Capio and Carema). Many new private service providers emerged after 2010, when the County Councils were ordered to organize primary health services so that users could freely choose providers, in line with the law on freedom of choice (LOV 2008: 962). Most of the new health services are established in highly populated areas, as one would expect. Consequently, half a million people have a second provider within a 5-min drive from their residence, so the number of options has increased for many (Swedish Competition Authority 2010). Availability is important as one of the preconditions for real consumer choice. However, these kinds of concentration and distributional effects indicate that this is only the beginning of the structural transformations in Swedish welfare resulting from increased freedom of choice and free rights to establish private institutions. Larger social differences in access 
to welfare services may be a consequence if there are no regulations on establishment.

The opening up for private competition within the public welfare services in Sweden has strengthened the for-profit sector but not the so-called "ideal sector" with strong ties to civil society organizations. Government-funded welfare contracts in Sweden have attracted private investors and venture capital even from international funds. The institutional and legal changes promoting private competition to the public service provision have resulted in commercial stimuli strong enough to transform the welfare model in a few decades. This is quite an unusual achievement in the welfare area, which is often described as a retrenched policy field (Pierson 2001). The question is whether there are unintended consequences as well, such as a small nonprofit sector, high concentration in ownership, no clear improvement in efficiency, and quality problems, such as the school results may indicate (Hartman 2011).

\section{Norway: A Stable Nonprofit Share of Welfare Employment}

In Norway, there has been an intense debate on the privatization of welfare services. It has focused on public versus private services, while the nonprofit sector often has been left out of focus. Despite this, we have not seen such dramatic changes as in Sweden. The centre-right minority government in office from 2001 to 2005 wanted to make it easier to establish private schools in Norway. The red-green coalition government that followed immediately put on the brakes before the reform gave any results of importance for the welfare provider mix. This was in line with the red-green cooperation statement expressing the wish to give the voluntary sector good conditions for providing noncommercial services (Soria Moria-erklæringen 2005). Procurement regulations allowed nonprofit organizations to be selected for closed tenders or negotiations about service contracts. In some areas, as in child welfare, the red-green government's goal was to select nonprofit organizations rather than commercial firms when the public sector itself did not have sufficient 
capacity (Sivesind 2008a). However, many structural welfare reforms have led to a decentralization of responsibility for the contracting of welfare services to more autonomous agencies, and this makes it difficult to implement such political intentions. Examples of such semi-autonomous agencies are regional state-funded child welfare and family counselling services (Bufetat) and regional health authorities (helseforetak) governed in a similar way as a private company with a director appointed by a board. The conservative minority coalition government from October 2013 has looked for opportunities to open up more for for-profit actors and user choice in health and social services. However, a new law in 2015 for private primary schools and secondary schools still requires that all public funding is used for educational purposes and not for profit distribution. The nonprofit providers continue to be involved in publicly funded services in areas where they have been innovators, such as elderly care, substance abuse treatment, medical rehabilitation, and somatic and mental health care. This results in a mixed model of public, nonprofit, and for-profit provision, to a large extent based on a patchwork of ad hoc policies that have emerged over a long time in different localities and service areas. Table 2.5 shows that the for-profit employment shares have increased in all service areas, and the nonprofit sector has had small increases in shares too, while the public sector has decreased between 2006 and 2013. However, since the total welfare employment has expanded, all sectors have had real increases in all service areas. The growth in the for-profit sector is primarily due to expansion in social services from 30,000 to 46,000 full-time employees, including elderly care, day care for children, child and juvenile welfare, and substance abuse treatment. There is a corresponding loss in public sector employment shares, despite real growth from 176,000 to 213,000 full-time employees. In real numbers, the nonprofit employment increased strongly from about 39,000 to 49,000 full-time employees. Ironically, media have mainly focused on nonprofit institutions that have been closed down. However, this has been more than compensated by employment growth in other institutions, which shows that the nonprofit sector also can be flexible and entrepreneurial under the right circumstances. The following analysis focuses on in which type of services the changes have happened. 
Table 2.5 Paid employment in the nonprofit, for-profit, and public sector within education, health and social services in Norway 2006-2013, full-time equivalent employment and percent

\begin{tabular}{|c|c|c|c|c|}
\hline \multirow[t]{2}{*}{ Service area } & \multicolumn{2}{|l|}{2006} & \multicolumn{2}{|l|}{2013} \\
\hline & Employment & $\%$ & Employment & $\%$ \\
\hline \multicolumn{5}{|l|}{ Education (2) } \\
\hline Nonprofit & 8,177 & 5.1 & 10,609 & 5.8 \\
\hline For-profit & 7,123 & 4.5 & 9,991 & 5.5 \\
\hline Public sector & 144,700 & 90.4 & 162,300 & 88.7 \\
\hline Total & 160,000 & 100.0 & 182,900 & 100.0 \\
\hline \multicolumn{5}{|l|}{ Health (3) } \\
\hline Nonprofit & 7,642 & 5.5 & 9,122 & 5.7 \\
\hline For-profit & 23,558 & 16.9 & 28,278 & 17.6 \\
\hline Public sector & 108,500 & 77.7 & 123,300 & 76.7 \\
\hline Total & 139,700 & 100.0 & 160,700 & 100.0 \\
\hline \multicolumn{5}{|c|}{ Social services (4) } \\
\hline Nonprofit & 23,198 & 10.1 & 29,881 & 10.3 \\
\hline For-profit & 29,902 & 13.1 & 46,219 & 16.0 \\
\hline Public sector & 175,600 & 76.8 & 213,100 & 73.7 \\
\hline Total & 228,700 & 100.0 & 289,200 & 100.0 \\
\hline \multicolumn{5}{|c|}{ Welfare field in total } \\
\hline Nonprofit & 39,017 & 7.4 & 49,612 & 7.8 \\
\hline For-profit & 60,583 & 11.5 & 84,488 & 13.4 \\
\hline Public sector & 428,800 & 81.2 & 498,700 & 78.8 \\
\hline Total & 528,400 & 100.0 & 632,800 & 100.0 \\
\hline
\end{tabular}

Sources: See appendix at the end of the chapter

Statistics Norway does not publish employment data separately for the economic sectors and has not yet implemented the ESA2010 institutional sector codes as Statistics Denmark has done. Table 2.5 is therefore based on full-time employment data from the Satellite Account for Non-Profit Institutions and employment data for the public sector, seen in relation to national account data for the welfare services in total. However, Table 2.6 presents data only from Statistics Norway's Satellite Account for Non-Profit Institutions and shows the changes in employment within the nonprofit sector in Norway. Similar detailed data do not exist for the other sectors. The other Scandinavian countries are in the process of implementing such satellite accounts but have not yet published full reports. 
Table 2.6 Paid full-time equivalent employment in the nonprofit sector in the welfare field in Norway 2006-2013

\begin{tabular}{|c|c|c|c|}
\hline Type of service & 2006 & 2013 & $\begin{array}{l}\text { Change } \\
2006-2013\end{array}$ \\
\hline Education & 8,177 & 10,609 & $29.7 \%$ \\
\hline Primary and secondary education & 4,395 & 6,031 & $37.2 \%$ \\
\hline Higher education & 1,736 & 2,136 & $23.0 \%$ \\
\hline Other education & 2,046 & 2,442 & $19.4 \%$ \\
\hline Health & 7,642 & 9,122 & $19.4 \%$ \\
\hline $\begin{array}{l}\text { Hospitals, rehabilitation, mental health } \\
\text { care and other health services }\end{array}$ & 7,642 & 9,122 & $19.4 \%$ \\
\hline Social Services & 23,198 & 29,881 & $28,8 \%$ \\
\hline Nursing homes ${ }^{a}$ & 4,765 & 5,543 & $16.3 \%$ \\
\hline Day care for children & 12,161 & 14,724 & $21.1 \%$ \\
\hline Child and juvenile welfare & 1,000 & 1,045 & $4.5 \%$ \\
\hline Substance abuse treatment & 2,012 & 2,244 & $11.5 \%$ \\
\hline $\begin{array}{l}\text { Other social services including } \\
\text { emergency and relief }\end{array}$ & 3,260 & 6,325 & $94.0 \%$ \\
\hline Total welfare employment & 39,017 & 49,612 & $27.2 \%$ \\
\hline Nonprofit share of welfare employment ${ }^{b}$ & $7.4 \%$ & $7.8 \%$ & \\
\hline
\end{tabular}

Source SSB Satellite account for non-profit organizations. Table 08520, FTE employment by activity (ICNPO)

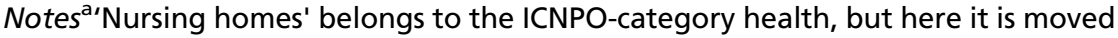
to social services to match with Table 2.5, which is set up in line with SN2007, which is Statistics Norway's version of EU's NACE Rev.2.

b Welfare employment in all sectors from SSB National economy. Table 09174, FTE employment in Education, Health, and Social Work

The strongest growth within the nonprofit sector in Norway was in primary and secondary education. Table 2.6 shows that the number of full-time employees has increased from 4400 to 6000 from 2006 to 2013. This happened despite stricter requirements for the establishment of new schools from 2007 to 2015 . In practice, only noncommercial and established educational alternatives such as Waldorf and Montessori schools were approved. In secondary schools, there has also been strong growth from 1700 to 2100 full-time employees, but still only $7 \%$ of students in upper secondary and 3\% in compulsory education are in private, nonprofit schools in 2014/2015 (Norwegian Directorate for Education and Training 2015). As we will see in the next chapter of this book, in primary and secondary education, the relations between the 
public sector as funder and the private providers are regulated by service concessions and not by tendering under the Public Procurement Act. This means that there is an opening for private initiatives to establish new schools as long as they can get approval by the Directorate for Education. This has resulted in an increase in the number of primary and lower secondary schools from 165 to 209 and upper secondary schools from 83 to 94 between 2010 and 2014 (Norwegian Directorate for Education and Training 2015), despite lack of enthusiasm for private schools from the red-green government in position between 2005 and 2013. In many cases, this has been schools that the municipalities want to close down because of too few pupils. In 2014 and 2015, 27 and 28 new primary or secondary schools received approval from the Directorate for education under the new conservative government. This means an increase in the nonprofit sector since the law requires that all public funding has to be used directly for educational purposes, although some of the schools in fact are limited companies. However, some schools rent space in properties and buy services from companies with the same owners as the schools. The educational authorities have opened investigations when prices are significantly higher than the general market level. This shows that it takes vigilance to sustain a nonprofit model when for-profit companies are allowed to own schools.

The category 'Higher education' in Table 2.6, which, for example, includes the BI Norwegian Business School and diaconal colleges engaged in nursing education, expanded from 1700 to 2100 full-time employees, and 'Other education,' which includes folk high schools and other forms of adult education, had an employment growth from 2000 to 2400. This is on par with the growth of the welfare field in total. Nonprofit organizations in 'Education' in total had an employment growth from 8200 to 10,600 and constituted $5.3 \%$ of all employment in this area in Norway (Statistics Norway 2016a).

The main category 'Health' in Table 2.6 includes only 'Hospitals, rehabilitation, mental health care, and other health services', 5 which grew from 7600 to 9100 full-time employees. This includes not only several diaconal hospitals but also other forms of nonprofit psychiatric centers and rehabilitation institutions. A large part of this is services that are purchased by the regional state health authorities in Norway. The 
nonprofit somatic and mental health hospitals and clinics are well integrated into that system for allocation of service contracts, because of their large capacity and special competence. The contracting authorities have had the opportunity to reserve tenders and negotiations with the nonprofits, in line with an exception to the rules on public procurements introduced in 2004 (see Chap. 3). However, this has not been used here because the for-profits do not have the necessary kind of capacity. Rather, they are involved in laboratories, radiology, and minor surgery. A large part of the for-profits public funding comes from patients with certain diagnoses that may choose from a list of public and private providers.

In rehabilitation, the contracting authorities buy services in a single market because they find it difficult to distinguish between nonprofit and for-profit providers. All in all, there is little direct competition between nonprofit and for-profit providers in health. The challenge for the nonprofit sector is instead that the public sector may decide to expand its own activities (Bogen and Grønningsæter 2016). However, the nonprofit sector also has activities outside the public procurement system and continues to develop new services such as low-threshold health services for drug addicts and for migrants who lack documents. These kinds of humanitarian tasks are difficult for the state or private companies to be legally responsible for.

Within the main category 'Social services,' the growth in nonprofit employment was from 23,200 to almost 30,000 between 2006 and 2013, as Table 2.6 shows. 'Nursing homes' includes both home care and institution-based care, which is largely a municipal responsibility. Nonprofit employment here grew from 4800 to 5500. Many municipalities have only public service providers, but about 70-80 nonprofit nursing homes have long-term framework agreements. Very few have got an operating contract through competitive tendering. There are only about 20 for-profit nursing homes that are part of the municipalities' normal systems for user allocation, but in addition, some private institutions sell single places to municipalities (Vabø et al. 2013, 180-181).

In total for institutions for the aged and disabled, almost $90 \%$ of all beds are operated by the municipalities. The for-profits increased their share from $4 \%$ in 2009 to $7 \%$ in 2015, while the nonprofits decreased from 6 to 5\% (Statistics Norway 2016d). The for-profit share is still 
surprisingly small when seen in relation to the intense political debates in the Norwegian election campaigns about 'out-contracting of grandma' (Vabø 2011). There has been much enthusiasm for increased competition and user choice, but an administrative separation between contracting agencies and service providers have primarily been used to improve cost and quality control. Only $4 \%$ of Norwegian municipalities had introduced user choice in elderly care in 2012 (NHO Service 2013). However, this includes the biggest cities, Bergen and Oslo, with many users. Within home-based care, the public share of the costs is $97 \%$, while the rest is split between for-profit and nonprofit contractors (NHO $2015,77)$. In the small area of practical user-steered assistance 6 - publicly funded personal services mainly for people with disabilities-the nonprofit organizations have a major part because the private services, to a large extent, are organized through a cooperative called $\mathrm{ULOBA}^{7}$ (NHO 2015; NHO Service 2010).

The dominant area in social services is day care for children, with 12,000 full-time employees in 2006 and 14,700 full-time employees in 2013. However, this is a field where the for-profit companies had an even stronger growth from 12,000 to 20,000 full-time employees in the same period as a result of generous public funding arrangements designed to finally reach full coverage of the demand for day care. As a result, the nonprofit share decreased from 22 to $20 \%$, while the for-profit share increased from 22 to $27 \%$ of total full-time employment in kindergartens from 2006 to 2013 (Statistics Norway 2016c). In child welfare, we find institutions and homes funded by the state's Children, Youth, and Family Service (Bufetat) with its 5 regional offices. The red-green coalition government wanted to reduce the use of commercial organizations in this field. This may be part of the reason for nonprofit employment growth from 1000 to 1200 full-time employees from 2006 to 2008 (not shown in Table 2.6), but in 2013 the employment was down to the same level as in 2006 again. Other data indicate that the for-profit full-time employment in public contracts increased by more than 50\% from 2007 to 2015, while the nonprofit and public sectors were stable (Statistics Norway 2016b). One reason for this may be that some regions have changed from the traditional framework agreements to 
tenders, and in open competition the for-profits tend to have an advantage.

In substance abuse treatment, which for the most part is services that the state health authorities buy, the nonprofit employment grew from 2000 to 2200 full-time employees (Table 2.6). This despite the fact that here too there have been increasing demands on documentation and some nonprofit institutions have been shut down (Bogen and Grønningsæter 2016). However, the nonprofit employment still grows because they are an important part of the substance abuse treatment with specific competencies and have had up to $40 \%$ of the total capacity in some regions (Hatlebakk 2014).

The backdrop for these changes is a number of comprehensive welfare reforms have increased the use of open tendering and quasi-markets in Norway. In some areas, competition for contracts only applies to the operation of new institutions and services, or just between the private providers, while in a few areas there is competition between public, for-profit, and nonprofit actors. The reforms have created special challenges for the nonprofit organizations because open tenders demand a lot of resources, the contracts often have a short duration, and methodological and ideological alternatives may not be much of a competitive advantage, despite the fact that user choice and adaptation have been requested by the politicians. There is an apparent tendency for the for-profits to take market shares when there is an open competition with the nonprofits, such as we have seen in kindergartens, child and family protection, and nursing homes in a few municipalities. The sectors have different advantages. The voluntary actors have in particular stood for the distinctive alternatives, although they are not always good at communicating that to the outside world (Trætteberg and Sivesind 2015). The profit-oriented companies on their side emphasize cost control and user satisfaction and often have a more professional system for quality measurement and preparation of tender documents. This may be because they have access to competence and capital from welfare concerns owned by private investors. This makes them more able to expand in a competitive environment.

All in all, Norway has a mixed model; there is a strong dominance of public welfare provision in some areas, combined with a small share of 
nonprofit actors. However, increased use of quasi-markets and open tendering in some areas has brought for-profits to grow faster than the nonprofits, in particular in social services. This has resulted in a decrease in the public share of the growing welfare employment.

\section{Nonprofit Stagnation and For-Profit Growth}

The composition of welfare providers in publicly funded services in the Scandinavian countries is diverging. Sweden now has the largest for-profit share-and it is still growing. In Norway and Denmark, the for-profits also grow faster than the nonprofit providers. In Denmark, there has even been a slight decline in the nonprofit share, but it is still large by Scandinavian standards. These changes are mainly due to changes in social services. The nonprofit sector in Sweden remains small, although the policy is intended to promote alternatives to the public services. This is because the private growth is stimulated by commercial incentives, while there are no tools for regulating the balance between the public, for-profit, and nonprofit sectors. ${ }^{8}$ The for-profits have better access to the economic resources necessary to establish new service institutions that then seek approval from the government agencies based on general criteria. After that, it is up to the users to choose providers. This freedom of choice adds an important quality dimension. However, the Swedish nonprofits, which lost much of their institutional foothold before 1990, have difficulty with raising capital to expand their services in this new regime (Swedish Government Inquiries SOU 2016:78). Consequently, they are unable to realize their potential for providing a broader offer of qualitatively distinctive alternatives that the economic nonprofit theories emphasize (Weisbrod 1977; Steinberg 2006).

There are also differences between the service areas in the three Scandinavian countries. In education, the nonprofits are able to keep their employment shares. However, in Sweden, the for-profits have had a very strong growth. In Norway and Denmark, the nonprofit schools are still the only alternative to the public school system due to requirements for public funding, as we will see in the next chapter. 
In health, only Norway has a share of nonprofit service providers of any significance. This is because they, in particular in somatic and psychiatric institutions and substance abuse treatment, are well integrated into the public specialist health system (Bogen and Grønningsæter 2016). In Sweden, there has been a decrease in the public sector and a strong growth in the for-profit shares, which has brought them up to the same level as in Norway and Denmark. This growth will probably continue because there is free right to establish new health services, provided that they get public approval.

In social services, the for-profits have had a stronger growth than the other sectors in all Scandinavian countries. This is the most important reason for a change in total shares of welfare providers in Scandinavia from the public sector to the for-profit sector. This has to do with increasing use of market-emulating tools of governance, such as open tenders, short-term contracts and increasing competition between the sectors. Additionally in Denmark, there have been several reforms that have reduced the nonprofit employment in social services in the short term. Consequently, the nonprofit sector's share goes down while the public and for-profit shares increase. It is too early to say if this is a new trend because the changes in full-time employees are quite small.

In general, nonprofit service providers have not been put under the same competitive pressure in the social services in Denmark as in the other Scandinavian countries. This is because several Danish municipalities include self-owning institutions in an in-house system for allocation of users instead of open tendering. Furthermore, the nonprofit schools have a positive development in Norway and Denmark, while the for-profits grow rapidly in Sweden. The difference is that the service concessions do not allow distribution of profit in publicly funded schools in Norway and Denmark. The self-owning institutions and smaller companies still dominate in Denmark, while there is an increasing concentration of for-profit ownership in a few conglomerates in Sweden and Norway. This shows that the changes in the mix of welfare providers are influenced by the different tools of governance used by the Scandinavian countries. 


\section{Why is the Mix of Welfare Providers in the Scandinavian Countries Diverging?}

The changes in mix of providers of services funded by the public sector are primarily a result of policies responding to the particular situation in each country 15-20 years ago. Denmark has for a long time politically wanted to provide good and stable conditions for nonprofit welfare provision but has recently allowed for-profit provision in most service areas; Sweden wanted to decrease the public sector dominance in welfare provision and has created commercial incentives that promote growth in for-profit private services; while Norway has preferred public provision as long as there is sufficient capacity, in particular in the most basic types of health services and social care. Nonprofit providers have been invited to closed negotiation and tenders in certain areas, while for-profit providers have been used to increase capacity primarily in kindergartens, child and family protection, and some other social services. This has resulted in diverging changes in employment shares between the nonprofit, for-profit, and public sectors in the welfare services among the Scandinavian countries. The differences are so large that one may ask if there still is such a thing as a Nordic welfare model.

This divergence is happening despite broad implementation of New Public Management tools of government in all the Scandinavian countries. Not many years ago, few considered quasi-markets as a suitable coordination mechanism within the Scandinavian welfare model. Now, the strong prevalence is striking. This is partly a consequence of EU's public procurement directive with formal requirements to open tenders for contracts over a threshold value. ${ }^{9}$ This directive also applies to Norway, which is not an EU member, due to the EEA treaty. However, the national regulation of public procurement in the Scandinavian countries is in many ways stricter than the EU directive, which will be a topic in the next chapter.

Some have assumed that the spread of market-emulating governance would result in convergence between the welfare regimes (Henriksen et al. 2012). Looking at the mix of welfare service providers, however, there is rather divergence among the Scandinavian countries-and with 
other welfare regimes. Sweden still has less nonprofit welfare service provision than any of the western European countries, but this is now combined with a rapidly growing for-profit share. The liberal countries tend to have much larger nonprofit sectors, whereas in the welfare partnership countries, the third sector plays a much larger and more independent role as welfare provider (Anheier and Salamon 2006; Salamon et al. 2004; Sivesind and Selle 2009; Salamon and Sokolowski 2016). In addition, the government, and not the market or the employment-based social insurances, remains the main source of funding for core welfare services in all Scandinavian countries. Denmark has a nonprofit share on a level between the other Scandinavian countries and the welfare partnership model, but this is a result of self-owning institutions and free schools and not semi-public welfare associations with dominating roles in welfare provision as in the welfare partnership countries. In those service areas that have been opened up for private providers, Norway has gone further in allocating contracts by open tenders than the other Scandinavian countries, which has resulted in for-profit growth. However, in other areas, the nonprofit share has been protected by continuation of framework agreements, particularly in nursing homes, and by closed tenders and negotiations in areas like child and family protection. Still, there has been little focus on taking advantage of the nonprofit sector's potential distinctiveness among the contracting agencies (Trætteberg and Sivesind 2015). All in all, the diverging development trends between the Scandinavian countries are a result of policy responses to different compositions of welfare service providers in each country that had evolved before the NPM tools were implemented. However, welfare reforms were also motivated by different political ideologies.

This is not the place to go through the long historic development of variations of the social democratic welfare model among the Scandinavian countries, but Sweden's development of a welfare model has been characterized by a centralized and paternalistic corporatism. According to Tim Knudsen and Bo Rothstein (1994), this was a result of a system of estate representation that was gradually changed to a liberal society. In Denmark, in contrast, there was an abrupt shift from modern absolutism to a representative democracy in 1848-1849. The end of 
absolutism was brought about by liberal movements, based on both farmers and liberal bourgeoisie. These forces demanded that alternatives to the public schools should get financial support from the public sector, resulting in a pragmatic welfare liberalism (Knudsen and Rothstein 1994). This turned out to be a model where different social groups could create institutions promoting certain views of life, values, pedagogies, or activities.

The different welfare models in Sweden and Denmark can also be recognized in the development after WWII. Sweden focused on developing welfare services provided by the public sector in order to reduce social inequality, to a large extent with support of the civil society (Rothstein and Trägårdh 2007). In Denmark, there was broad political support also for alternatives to the public sector, and the self-owning institutions and free schools could continue to evolve independently of which political parties were in government. By the beginning of the 1990s, Sweden had an extremely large public welfare employment share. For Sweden, the expansion of the private welfare provision after 2000 could be seen as steps towards becoming a normal, western welfare society. In Denmark, changes seemed less urgent. The larger nonprofit sector represented more distinct alternatives for choice, and volunteering and civic engagement were politically promoted as antidotes to bureaucratization and passivity that could be the result of a self-contained public welfare system (Henriksen and Bundesen 2004).

In Norway, the nonprofit sector's role was smaller than in Denmark and more fragmented, and the public policy towards it was often particularistic and pragmatic. Long-term collaborative relationships between the public sector and the nonprofit providers evolved in services like elderly care, substance abuse treatment, and health care, often as the result of the strength of counter-cultural popular movements in the peripheral districts related to lay Christian communities, new Norwegian language, or temperance (Sivesind and Selle 2010; Rokkan 1967). In the 1980 s, privatization of welfare services was put on the agenda by a conservative political surge, and there has recently been for-profit growth in particular in social services like kindergartens, child and family protection, and rehabilitation. 
However, as we have seen, in elderly care the changes in the welfare provider mix have been small, despite fierce political debates (Vabø 2011). Even in large municipalities close to larger cities with a conservative majority, only one or two institutions for elderly care have typically been out-contracted to for-profit providers. This is done to establish a market price that is then used for benchmarking of similar public sector services. Because of good economic conditions and expanding welfare employment, there have been less urgent needs to cut costs by contracting out services. In many welfare areas, it has even been difficult to get enough qualified professionals in the public sector. Private employers with lower pay and inferior pension systems would have little to offer in such a tight labour market. In addition, there was a strong resistance against privatization fronted by the Norwegian Union of Municipal and General Employees (Fagforbundet), which is the largest union in The Norwegian Confederation of Trade Unions (LO Norway) with nearly 340,000 members. Instead of just arguing for status quo, they collaborated with other trade unions and the Norwegian Association of Local and Regional Authorities (KS) and political authorities to initiate several programs for improvement of services in the municipalities that ran subsequently from 1998 to 2015, in many cases with measurable success (Vabø et al. 2013, 185-188). In many municipalities, framework agreements with nonprofit providers have been prolonged, but in the cases where there has been open tender competition, the for-profit providers tend to prevail, if not in the first round, then in almost all cases in the second round of tendering (Herning 2015). In Sweden, the public sector was under stronger pressure to cut costs, and private service providers in elderly care could offer lower costs than services provided in-house by the municipalities (see Chap. 4 by Feltenius).

Like the other Scandinavian countries, Sweden implemented NPM and quasi-markets as tools of governance. However, in Sweden, additional steps were taken to create competition between the public and private welfare providers. A centre-right government from 1991 to 1994 opened up for competitive tendering and user choice in the municipalities. The social democratic governments from 1994 to 2006 did not reverse these reforms, and the for-profit employment share kept increasing. There was a debate within the social democratic party 
between the 'state-socialists,' who wanted to stop the for-profit welfare growth and the 'popular movement democrats,' who did not see public monopoly on service provision as a precondition for a social democratic welfare state (Trägårdh 2007). At the party congress in 2001, this controversy resulted in a compromise involving an enquiry about nonprofit institutions (Lindbom 2013) that in retrospect has been of little consequence.

From 2006 to 2014, the centre-right minority government went even further by strengthening general rights for user choice (Freedom of Choice Act, LOV 2008: 962), which includes funding through some kind of voucher systems, reduced barriers for establishment of new welfare services depending on approval by national public agencies, and no restrictions on transferring profit to owners. The intention was to reduce the public sector dominance by creating effective quasi-markets where the users can reject service providers they dislike, and with low barriers for establishment of new service providers. The goal was to create a dynamic where bad institutions would disappear and good institutions would take over. However, an unintended consequence has been that a very large share of the for-profit companies is owned by a few conglomerates with vested interests in health, education, and social services. Politicians also argue that stronger and more direct measures against low performing institutions are necessary in the public as well as the private sectors.

The venture capitalists may not be taking out revenue from the companies on a regular basis, even if they have legal right to do so. If they can develop services and expand the business, they can sell with a profit after some years. This opportunity to buy and sell shares has introduced an incentive to growth for private companies. However, it does not work on the nonprofit actors. Their main concern is developing distinct service profiles in terms of religion, ideology, or methods, and they may therefore not be interested in competing on a bid to take over a welfare institution with its employees, maybe only to lose it again after a 3-year period. It takes time to form services in line with the organization's main goals. Growth is not a goal in itself. Nonprofit welfare providers may also have a more local basis and therefore lack capital reserves to come back if 
they lose the contract to operate a particular institution. In the long run, the for-profit providers prevail, and this endangers provision of qualitatively different services that, according to some economic theories, are characteristic for the nonprofit sector (Weisbrod 1977), and such distinct alternatives to choose from may be important for the long-term support of government-funded welfare services. A study by Dahlberg et al. shows that in service areas with the implementation of user choice in combination with rights to establish new service units in Sweden, there seems to be faster growth in the for-profit sector than in areas with competitive tendering. When the law of freedom of choice is implemented through one political decision on the national level, as it was in primary health care in 2010, this speeds up the for-profit growth (Dahlberg et al. 2013, 226).

Service providers owned by welfare conglomerates are emerging as a new type of actor with their own interests, business partners, and strategic alliances in politics and public administrations, which in turn results in improvement in their own framework conditions. When politicians that are sceptical of privatization come to power at the national, county, or local level, they may have stopped the acceleration but seldom reversed previous reforms. Political goodwill for the nonprofits is not enough to increase their share of the welfare employees when they are regulated in the same way as the for-profits. The growth incentives continue to work on the for-profit sector and not on the nonprofit sector, and the long-term result will be a fundamental change of the Swedish welfare model.

In all the Scandinavian countries, the nonprofit welfare providers enjoy broad political support, and the governments have even signed compacts with the voluntary organizations providing health services and social care, inspired by a similar agreement made in the UK (Johansson and Johansson 2012). The intention is to establish shared principles and guidelines for effective and high-quality services and dialogue while securing predictability, autonomy, and distinctiveness for the voluntary organizations. In Denmark, the compact signed in 2001 is a rather general declaration of interests, and it is difficult to put the finger on concrete results. Still, the compact was renewed in $2013 .{ }^{10}$ However, we 
see clear effects of long-term, broad political support, and a highly institutionalized relationship between the government and the nonprofit organizations. An example of this is that the municipalities are stimulated by the government to involve voluntary organizations on the social service field by special funding ( $\$ 18$-collaboration between the municipalities and voluntary social organizations).

In Norway, the compact is followed up by dialogue meetings between the Minister and representatives of organizations once or twice a year. Since it was signed in October 2012, there are examples of tenders and negotiations that are only open to nonprofit actors, and also of a new type of service contracts that do not have a fixed termination date. When we consider the Norwegian nonprofit sector's growth (Table 2.6), there seems to be an effect of the red-green coalition government's (20052013) willingness to prioritize nonprofit organizations when the public sector itself does not have sufficient capacity. The conservative coalition government from 2013 also supported the compact, but has been more in favour of sector neutral policies. The for-profit sector has had a stronger growth rate as a result of the strategy of several governments to increase capacity through generous funding arrangements in areas like kindergartens.

In Sweden, the nonprofit sector did not have a real foothold before the privatization process started in the 1990s and has been lagging behind. Even though the compact that was signed in 2008 has a very elaborate strategy for stimulating regional and local processes, this has not resulted in an increase in nonprofit employment shares. It is difficult to create growth when the sector is reduced to a minimum and lacks effective framework conditions for growth. In addition, the population has little previous experience with distinctive nonprofit sector services so it is difficult for the stakeholders to muster broad political support.

A general finding from this comparison of welfare service areas and institutional sectors in Scandinavia is that competitive tendering results in for-profit growth and nonprofit stagnation or decline. It is difficult to find one example of a welfare area in Sweden and Norway where this is not the case. In Denmark, such changes are not yet so easy to see in the statistics because of a stronger tradition for nonprofit sector services. 
However, recent reforms may encourage increasing for-profit shares in Denmark too. By comparing the tools of governance used by the Scandinavian countries, it becomes clear that equal opportunities and political goodwill are not sufficient to develop a distinctive nonprofit sector with critical mass. It takes long-term contracts and restrictions on transfer of profits, a clear preference for the distinctive features of the nonprofit providers, or negotiations or tenders reserved for nonprofits.

For example, the nonprofit sectors in Norway and Denmark have in particular had a strong position in primary and secondary education, which is regulated by service concessions with nonprofit status as a condition for approval, and not by competitive tendering. Another example is in-house law that is used to promote self-owning institutions in kindergartens and elderly care in Denmark. This shows that a differentiated welfare provider mix depends on differentiated types of regulation. However, this is not often recognized in political debates about how to reduce the public sector dominance and to increase competition, where arguments about equal competition dominate. Changes in the welfare provider mix, and in particular the share that remains for the nonprofit sector, tend to be unintended consequences rather than clearly formulated political goals. Denmark has been an exception so far, but now privatization and competition are becoming goals in themselves, and new regulations open up for profit-oriented companies in more service areas.

NPM tools are used to regulate the relation between the government's contracting agencies and welfare service providers in the public, for-profit, and nonprofit sectors in all Scandinavian countries in similar ways as in many other European countries. As such, this does not result in diverging welfare models. The social democratic welfare ideals, funding model, and a certain share of nonprofit services can be sustained together with these tools of governance, as we have seen in Denmark and in some service areas also in Norway. However, Sweden has chosen to implement an additional set of policy instruments, including increasingly broad enactment of user choice and reduced restrictions on the establishment of new welfare institutions, combined with no limits on transfer of profits. This has set in motion rapid and broad expansion of the for-profit sector with a long-term 
regime-changing potential. A diversified welfare mix depends on diversified tools of governance, which includes reserved tendering and negotiations, service concessions, or in-house service contracts. This can be used to secure a certain nonprofit share in service areas where policymakers consider it to be particularly valuable. These different types of regulation and legal frameworks in the Scandinavian countries will be the topic of the next chapter.

\section{Notes}

1. This means the number of percentage points change divided by the total number of years and multiplied by five. For total welfare employment, percent change is divided by total number of years and multiplied by five. Five-year periods are chosen because 1 year change would result in very small numbers, and the focus here is on cumulative long-term changes.

2. The real employment numbers are shown in Tables 2.3, 2.4, and 2.5.

3. Maximum years are not shown in the Table.

4. The main source for the following presentation of changes in the Danish welfare mix is a report by Malene Thøgersen about self-owning institutions in Denmark (Thøgersen 2013).

5. 'Nursing homes' is moved to social services here to match with Table 2.5, which is set up in line with Statistics Norway's version of NACE.

6. "personlig brukerstyrt assistanse (PBA)».

7. ULOBA is a cooperative that is employer for the personal assistants for disabled persons who are stake owners.

8. A new Swedish Government Inquiry (SOU 2016: 78) suggests a replacement of the Freedom of Choice Act (LOV 2008: 962) that includes tools to promote the nonprofit providers and regulation of the level of profits, but it is doubtful if there is political support for this in the Parliament.

9. EU's public procurement directive 2004/18/EC, which was replaced with Directive 2014/24/EU http://eur-lex.europa.eu/legal-content/EN/ TXT/?uri=CELEX\%3A32014L0024.

10. http://www.frivilligcharter.dk/sites/default/files/attachments/Frivillighed scharter.pdf. 


\section{Appendix}

The definition of nonprofit organizations is based on UN's Handbook on Non-Profit Institutions in the System of National Accounts (United Nations 2003). The most important criteria are that the organization is not subordinate to public structures of governance, although substantial parts of the income may come from the public sector. The organization does not distribute profit to owners, directors, members, or others, which means that it does not primarily have a commercial orientation. The surplus must be used in line with the main goals of the organization.

The Danish data for nonprofit, for-profit, and total employment of the welfare area cover P Education and Q Health and social services in DB07, which is Statistics Denmark's version of EU's NACE Rev. 2. The source is Statistics Denmark's statistics bank, table «LBESK32: Fuldtidsbeskæftigede lønmodtagere efter branche (DB07 19-grp), sektor og tid». This is the only source of full-time employment data, but it only covers the years 20082013. To differentiate between health and social services, we use ratios for a number of employees from the table «RASOFF34 Beskæftigede lønmodtagere efter branche (DB07), sektor og tid». The data for nonprofit employment are estimates for the ICNPO categories Education, Health, and Social Services (Boje 2017, Table 4.10) except for the modifications described in Table 2.2 above. The data for nonprofit employment are higher than in table LBESK32, and this difference is subtracted from the public sector employment. This is because LBESK32 uses sector coding from ESA2010. This implies that self-owning institutions with operating contracts with the public sector according to the 'in-house' regulations are included in the public sector. However, according to the Handbook on NonProfit Institutions in the System of National Accounts (United Nations 2003), they should be part of the nonprofit sector. The calculation of employment in 2008 is based on the assumption that there has been a linear growth from 2003 to 2013, which are the two data points covered by the source (Boje 2017, Table 4.10).

The Norwegian data for nonprofit employment are from Statistics Norway's satellite account (Statistics Norway 2015) for the ICNPO categories Education, Health, and Social Services, except for the 
modifications described in Table 2.2 above. Table 2.5 is set up in line with SN2007, which is Statistics Norway's version of EU's NACE Rev.2. The for-profit employment data are the residual between the total employment and the public and the nonprofit sector.

The Swedish data do not show full-time employment but the number of employed persons from the table «Antal sysselsatta fördelat på sektor inom vård, skola och omsorg» in Statistics Sweden's 'Officiella Statistik Serie Offentlig Economi OE 29 SM 1001 2014' and 'OE 29 SM 1501 2015'. The services are classified according to SNI2007, which is Statistics Sweden's version of EU's NACE Rev. 2.

\section{References}

Anheier, K. Helmut, and Lester M. Salamon. 2006. The nonprofit sector in comparative perspective. In The nonprofit sector. A research handbook, eds. Walter W. Powell and Richard Steinberg, 90-114. New Haven: Yale University Press.

Bogen, Hanne, and Arne Backer Grønningsæter. 2016. En ideell forskjell? Om ideelle aktører $i$ spesialisthelsetjenesten. (Fafo-rapport 2016:30). Oslo: FAFO.

Boje, Thomas P. 2006. Den danske nonprofitsektor sammenlignet med andre europæiske lande. In Frivillighed og nonprofit i Danmark. Omfang, organisation, økonomi og beskaftigelse, eds. Thomas P. Boje and Bjarne Ibsen, 217224. København: Socialforskningsinstituttet.

- 2017. Civilsamfund, medborgerskab og deltakelse. København: Hans Reitzels Forlag.

Boje, Thomas P., Torben Fridberg, and Bjarne Ibsen. 2006. Den frivillige sektor i Danmark. Omfang og betydning. København: Socialforskningsinstituttet.

Dahlberg, Matz, Mikael Elinder, David Isaksson, Henrik Jordahl, Anders Lindblom, Ulrika Winblad, and Richard Öhrvall. 2013. Slutsatser. In Välfärdstjänster i privat regi. Framväxt och drivkrafter, ed. Henrik Jordahl, 221-230. Stockholm: SNS Förlag.

Erlandsson, Sara, Palle Storm, Anneli Strantz, Marta Szebehely, and Gunn-Britt Trydegård. 2013. Marketising trends in Swedish eldercare: Competition, choice and calls for stricter regulation. In Marketisation in Nordic eldercare: A research report on legislation, oversight, extent and consequences, eds. Gabrielle 
Meagher and Marta Szebehely, 23-84. Stockholm: Department of Social Work, Stockholm University.

Hatlebakk, Ingrid Myrset. 2014. Rusbehandling-mye i privat regi. Samfunnsspeilet (2/2014). Oslo: Statistisk Sentralbyrå.

Heikki, Ervasti, Torben Fridberg, Mikael Hjerm, Olli Kangas, and Kristen Ringdal. 2008. The Nordic model. In Nordic social attitudes in a European perspective, eds. Heikki Ervasti, Torben Fridberg, Mikael Hjerm, and Kristen Ringdal, 1-21. Cheltenham: Edward Elgar.

Henriksen, Lars Skov, and Peter Bundesen. 2004. The moving frontier in

Denmark: Voluntary-state relationships since 1850. Journal of Social Policy 33 (4): 601-621.

Henriksen, Lars Skov, Annette Zimmer, and Steven Rathgeb Smith. 2012. At the eve of convergence? Transformations of social service provision in Denmark, Germany, and the United States. VOLUNTAS: International Journal of Voluntary and Nonprofit Organizations 23 (2): 458-501.

Herning, Linn. 2015. Velferdsprofitørene. Oslo: Manifest forlag.

Johansson, Ola. 2011. Tjäna eller tjäna?-_om vård eller vinst. Privatisering av vård, omsorg, skola — vilka tar över? Stockholm: Famna.

Johansson, Håkan, and Mairon Johansson. 2012. From a 'Liberal' to a 'Social democratic' welfare state: The translation of the English compact into a Swedish context. Nonprofit Policy Forum 3 (2). doi:10.1515/2154-3348.1057. Knudsen, Tim, and Bo Rothstein. 1994. State building in Scandinavia. Comparative Politics 26 (2): 203-220. doi:10.2307/422268.

Laura, Hartman. 2011. Konkurrensens konsekvenser. Vad händer med svensk välfärd? Stockholm: SNS Förlag.

Lindbom, Anders. 2013. Socialdemokraterna och privat drift i välfärden: två idétraditioner. In Välfärdstjänster i privat regi. Framväxt och drivkrafter, ed. Henrik Jordahl. Stockholm: SNS Förlag.

Lundström, Tommy, and Filip Wijkström. 1997. The nonprofit sector in Sweden, The Johns Hopkins nonprofit sector series. Manchester: Manchester University Press.

NHO Service. 2015. Statistikk og trender 2015. Oslo.

. 2010. Omsorgstjenester. Bransjestatistikk 2011. Oslo.

- 2013. Status for valgfrihet i eldreomsorgen i Skandinavia. Oslo.

Norwegian Directorate for Education and Training. 2015. Skolefakta-Elevar, lerarar, skolar. Oslo.

Pierson, Paul. 2001. The new politics of the welfare state. Oxford: Oxford University Press. 
Report to the Storting (White Paper) nr. 29. 2012-2013. Future Care. Oslo: Helse- og omsorgsdepartementet.

Rokkan, Stein. 1967. Geography, religion, and social class: Crosscutting cleavages in Norwegian politics. In Party systems and voter alignments, eds. Seymor M. Lipset and Stein Rokkan, 367-444. New York: The Free Press. Rothstein, Bo, and Lars Trägårdh. 2007. The state and civil society in an historical perspective: The Swedish case. In State and civil society in Northern Europe. The Swedish model reconsidered, ed. Lars Trägårdh, 229-253. New York: Berghahn Books.

Salamon, Lester M., and Helmut K. Anheier. 1998. Social origins of civil society: Explaining the nonprofit sector cross-nationally. VOLUNTAS: International Journal of Voluntary and Nonprofit Organizations 9 (3): 213-248.

Salamon, Lester M., S. Wojciech Sokolowski, and Associates. 2004. Global civil society: Dimensions of the nonprofit sector, vol. II. Bloomfield, CT: Kumarian Press.

Salamon, Lester M., and S. Wojciech Sokolowski. 2016. The size and scope of the European third sector. Brussels: European Union FP7 (grant agreement 613034). Third Sector Impact.

Sivesind, Karl Henrik. 2008. Halvveis til Soria Moria. Ikke-kommersielle velferdstjenester, politikkens blinde flekk? Oslo: Institutt for samfunnsforskning. . 2008b. Nonprofit organisasjoner på velferdsfeltet i Norden. In Det frivillige Danmark, eds. Bjarne Ibsen, Thomas P. Boje, and Torben Fridberg, 161-178. Odense: Syddansk Universitetsforlag.

Sivesind, Karl Henrik, and Per Selle. 2009. Does public spending "crowd out" nonprofit welfare? Comparative Social Research. A Research Annual 26: 105134. doi:10.1108/S0195-6310(2009)0000026009.

Sivesind, Karl Henrik, Håkon Lorentzen, Per Selle, Dag Wollebæk, S.Wojciech Sokolowski, and Lester M. Salamon. 2004. Norway. In Global civil society: Dimensions of the nonprofit sector, vol. II, eds. Lester M. Salamon, S. Wojciech Sokolowski, and Associates, 261-275. Bloomfield: Kumarian Press.

Soria Moria-erklæringen. 2005. Plattform for regjeringssamarbeidet mellom Arbeiderpartiet, Sosialistisk Venstreparti og Senterpartiet 2005-09. Oslo, October 132005.

Statistics Norway. 2015. Table 08520: Full-time equivalent persons, by activity (ICNPO). Satellite account for non-profit institutions. https://ssb.no/orgsat.

- 2016a. National economy. Table 09174, FTE employment in Education, Health and Social Work. www.ssb.no/pleie. 
2016b. Table 07126: Children's institutions. Contractual man-years adjusted for long-term leaves, by region, age of the personnel and ownership of the institution. www.ssb.no/statistikkbanken.

. 2016c. Table 09339: Man-years in kindergartens, by ownership and employment position. www.ssb.no/statistikkbanken.

- 2016d. Table 09929: Institutions for the aged and disabled, by ownership. www.ssb.no/pleie.

Steinberg, Richard. 2006. Economic theories of nonprofit organizations. In The nonprofit sector. A research handbook, eds. Walter W. Powell and Richard Steinberg, 117-139. New Haven: Yale University Press.

Swedish Competition Authority. 2010. Uppföljning av vårdval i primärvården. Valfrihet, maingfald och etableringsförutsättningar. Slutrapport. Stockholm: Konkurrensverket.

Swedish Government Inquiries SOU 2016:78. Ordning och reda i välfärden. Stockholm: Ministry of Finance.

Swedish National Agency for Education. 2016. Skolor och elever i grundskolan läsåret 2015/16. Stockholm.

Szebehely, Marta. 2011. Insatser för äldre och funktionshindrade i privat regi. In Konkurrensens konsekvenser. Vad händer med svensk välfärd?, ed. Laura Hartman, 215-257. Stockholm: SNS Förlag.

Taylor-Gooby, Peter. 2008. Reframing Social Citizenship. Oxford: Oxford University Press.

Thøgersen, Malene. 2013. Selvejende institutioner i Danmark. Institutionernes udvikling, udbredelse og karakter på udvalgte samfundsområder. Aalborg: Netværk for forskning i Civilsamfund og Frivillighed.

Trætteberg, Håkon Dalby, and Karl Henrik Sivesind. 2015. Ideelle organisasjoners sartrekk og merverdi på helse- og omsorgsfeltet. Oslo: Senter for forskning på sivilsamfunn og frivillig sektor.

Trägårdh, Lars. 2007. The 'civil society' debate in Sweden: The welfare state challenged. In State and civil society in Northern Europe. The Swedish model reconsidered, ed. Lars Trägårdh, 9-36. New York: Berghahn Books.

United Nations. 2003. Handbook on nonprofit institutions in the system of national accounts. New York: United Nations.

Vabø, Mia. 2011. Active citizenship in Norwegian elderly care. From Activation to consumer activism. In Participation, responsibility and choice. Summoning the active citizen in Western European welfare states, eds. Janet Newman and Evelien Tonkens, 87-105. Amsterdam: Amsterdam University Press. 
Vabø, Mia, Karen Christensen, Frode Fadnes Jacobsen, and Håkon Dalby Trætteberg. 2013. Marketisation in Norwegian eldercare: Preconditions, trends and resistance. In Marketisation in Nordic eldercare: A research report on legislation, oversight, extent and consequences, eds. Gabrielle Meagher and Marta Szebehely, 163-202. Stockholm: Department of Social Work, Stockholm University.

Vlachos, Jonas. 2011. Friskolor i förändring. In Konkurrensens konsekvenser. Vad händer med svensk välfärd?, ed. Laura Hartman, 66-110. Stockholm: SNS Förlag.

Voitto, Helander, and Karl Henrik Sivesind. 2001. Frivilligsektorns betydelse i Norden. In Frivillighedens udfordringer, eds. Lars Skov Henriksen and Bjarne Ibsen, 49-66. Odense: Odense Universitetsforlag.

Weisbrod, Burton A. 1977. The voluntary nonprofit sector, an economic analysis. Lexington: D.C. Heath.

Wijkström, Filip, and Torbjörn Einarsson. 2006. Från nationalstat til näringsliv.

Det civila samhällets organisasjonsliv i förändring. Stockholm: Ekonomiska Forskningsinstitutet, Handelshögskolan i Stockholm.

Wiklund, Stefan. 2011. Individ- och familjeomsorgens välfärdstjänster. In Konkurrensens konsekvenser. Vad händer med svensk välfärd?, ed. Laura Hartman, 111-145. Stockholm: SNS Förlag.

- 2010. Civil society in the Nordic countries: Between displacement and vitality. In Nordic associations in a European perspective, eds. Risto Alapuro and Henrik Stenius, 89-120. Baden-Baden: Nomos Verlagsgesellschaft.

Zweifel, Peter, Carl Hampus Lyttkens, and Lars Söderström. 1998. Regulation of health: Case studies of Sweden and Switzerland, vol. 7, Developments in health economics and public policy. Boston: Kluwer.

\section{Author Biography}

Karl Henrik Sivesind is a research professor at the Institute for Social Research, Oslo, Norway. He is currently manager of the project 'Conditions and Impacts of Welfare Mix' funded by the Norwegian Research Council, and he is leader for Work Package 'Elaboration and Testing of Impact Indicators' on the project 'Third Sector Impact-The Contribution of the Third Sector to Europe's Socio-economic Development' funded by the EU's 7th Framework Programme. He has studied changes affecting civil society by analysing data from population 
surveys and local association surveys as a part of the activities of Centre for Research on Civil Society and Voluntary Sector in Oslo/Bergen. He has also been involved in several comparative research projects about the nonprofit sector and welfare services.

Open Access This chapter is licensed under the terms of the Creative Commons Attribution 4.0 International License (http://creativecommons.org/licenses/by/ $4.0 /$ ), which permits use, sharing, adaptation, distribution and reproduction in any medium or format, as long as you give appropriate credit to the original author(s) and the source, provide a link to the Creative Commons license and indicate if changes were made.

The images or other third party material in this chapter are included in the chapter's Creative Commons license, unless indicated otherwise in a credit line to the material. If material is not included in the chapter's Creative Commons license and your intended use is not permitted by statutory regulation or exceeds the permitted use, you will need to obtain permission directly from the copyright holder.

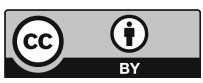

